\title{
Analisis Kepemilikan Atribut Soft Skills Mahasiswa Program Studi Pendidikan Ekonomi FKIP Univesitas Jambi
}

\author{
Zuhri Saputra Hutabarat ${ }^{1}$ \\ Correspondence email: zuhri.saputra.hutabarat@unbari.ac.id
}

\begin{abstract}
Tujuan dari penelitian ini untuk mengetahui atribut soft skill yang dimiliki mahasiswa, soft skill berdasarkan perangkatan dari 2015 sampai 2017, soft skill berdasarkan gender, dan soft skill berdasarkan asal mahasiswa. Metode penelitian menggunakan metode pendekatan penelitian survey dengan populasi seluruh mahasiswa program studi Pendidikan Ekonomi FKIP Universitas Jambi angkatan tahun 2015, 2016 dan 2017. Jumlah responden yang dijadikan sampel sebanyak180 orang. Adapun hasilnya: 1) Atribut soft skills yang sudah dimiliki mahasiswa secara keseluruhan sangat baik dengan Frekuensi Relatif 63,91\%. 2) Kemampuan soft skills mahasiswa secara per angkatan , 2015, 2016 dan 2017 sangat baik dengan frekuensi absolut 36 dan frekuensi relative 69,23\% dan Kemampuan Soft Skills Mahasiswa perangkatan mengalami kenaikan dari tahun 2015 sampai dengan 2017. 3) kemampuan Soft Skills mahasiswa berdasarkan gender ditemukan bahwa perempuan lebih tinggi dari pada laki-laki dengan kemampuan rata-rata sangat baik dengan hasil count 25 untuk laki-laki dan perempuan count 122. 4) Soft Skills mahasiswa berdasarkan asal dari kampung dan kota, hasil analisis diperoleh koefesien F hitung sebesar 0,218 dengan tingkat penolakan $64,10 \%$ dengan demikian tidak ada bedanya kemampuan rata-rata soft skills mahasiswa yang berasal dari kota dan dari desa. Saran dalam penelitian ini sebelum menggunakan instrumen penilaian soft skills mengenai hubungan interpersonal mahasiswa, kita harus terlebih dahulu mempelajari dan memahami petunjuk penilaian instrument, tata cara penilaian dan inti dari penilaian pada setiap rubriknya.
\end{abstract}

Kata Kunci: kemampuan, kepemilikan, Atribut Soft Skill

Abstract : This study aim to find out the soft skill attributes of students, soft skills based on devices from 2015 to 2017 , soft skills based on gender, and soft skills based on student origin. The method uses a survey research approach with a population of all Economics Education FKIP Jambi University students in the class of 2015, 2016 and 2017. The respondents as sampled was 180 people. As for the results: 1) The soft skills attributes that the students have overall are very good with a Relative Frequency of 63.91\%. 2) The ability of student soft skills from class, 2015, 2016 and 2017 is very good with an absolute frequency of 36 and a relative frequency of 69.23\% and Soft Skills Ability Student devices have increased from 2015 to 2017. 3) Student's Soft Skills based on gender were found that women were higher than men with very good average abilities with results of count 25 for men and women count 122. 4) Soft Skills students based on the origin of the village and the city, the results of the analysis obtained $F$ count coefficient of 0.218 with a rejection rate of $64.10 \%$ thus there is no difference in the average ability of students soft skills from the city and from the village. Suggestions in this study before using soft skills assessment instruments regarding student interpersonal relations, we must first study and understand the instructions for assessing instruments, assessment procedures and the core of the assessment in each rubric.

Keywords : ability, ownership, Soft Skill Attributes

\section{PENDAHULUAN}

Penelitian ini merupakan kelanjutan dari penelitian sebelumnya yang lebih fokus pada studi pendahuluan sebagai persiapan untuk melakukan penelitian ini. Pada penelitian ini lebih difokuskan untuk meneliti lebih lanjut kepemilikan atribut sof skill mahasiswa Program Studi Pendidikan Ekonomi FKIP UNJA, khususnya dalam aspek hubungan interpersonal. Penelitian ini sangat penting untuk diteruskan agar hasil akhkir penelitian ini yaitu bagaimana sesungguhnya kepemilikan atribut soft skills mahasiswa dapat diketahui yang hasilnya dapat dijadikan landasan pijak untuk merumuskan kebijakan yang tepat sesuai permasalahan yang ada.

Pada penelitian sebelumnya telah berhasil disusun instrument penilaian soft skills yang terdiri atas 69 butitr pernyataan. Instrument tersebut tergagi dalam 23 kategori. Kevalidan produk model instrument penilaian soft skills mahasiswa pendidikan ekonomi diperlukan dalam penelitian ini sebelum digunakan dalam dan diterapkan oleh mahasiswa prodi ekonomi. Hasil rekapitulasi tingkat kelayakan produk model

${ }^{1}$ Dosen Program Studi Pendidikan Ekonomi, Universitas Batanghari, Indonesia 
instrument penilaian soft skill mencapai 86,25\%. Presentase tersebut menunjukkan bahwa model instrumen penilaian soft skill ini berada pada kriteria sangat baik dan dapat digunakan oleh mahasiswa pendidikan ekonomi. Kevalidan tersebut dilihat dengan kesesuaian hasil uji kelompok kecil dan uji produk menggunakan model instrument soft skills mahasiswa ekonomi Dengan demikian hasil dari uji lapangan ini benar-benar dapat dipercaya.

Tujuan dari penelitian ini adalah untuk mengetahui atribut soft skill yang dimiliki mahasiswa, soft skill berdasarkan perangkatan dari 2015 sampai 2017, soft skill berdasarkan gender, dan soft skill berdasarkan asal mahasiswa. Metode penelitian menggunakan metode pendekatan penelitian survey dengan populasi seluruh mahasiswa program studi Pendidikan Ekonomi FKIP Universitas Jambi angkatan tahun 2015, 2016 dan 2017.

\section{Tinjauan Pustaka \\ Soft Skill}

Konsep tentang soft skill sebenarnya merupakan pengembangan dari konsep yang selama ini dikenal dengan istilah kecerdasan emosional (emotional intelligence). Soft skill sendiri diartikan sebagai kemampuan diluar kemampuan teknis dan akademis, yang lebih mengutamakan pada kemampuan intrapersonal dan interpersonal. Kedua kemampuan tersebut dapat dimiliki oleh seseorang melalui proses pembelajaran maupun proses pembiaasan dalam kehidupan sehari-hari.

\section{Atribut Soft Skills yang Dikembangkan}

Menurut Berthal (Illah Sailah, 2013) soft skills adalah "Personal and interpersonal behaviors that develop and maximize human performance (e.g. coaching, team building, initiative, decision making etc.). Soft skills does not include technical skills such as financial, computing and assembly skills ".

Berdasarkan penelitian yang dilakukan oleh negara-negara Inggris, Amerika dan Kanada, ada 23 atribut soft skills yang dominan di lapangan kerja. Ke 23 atribut tersebut diurut berdasarkan prioritas kepentingan di dunia kerja, yaitu (Muqowim, 2012:3):
1. Inisiatif
13. Manajemen diri
2. Etika/integritas
14. Menyelesaikan persoalan
3. Berfikir kritis
15. Dapat meringkas
4. Kemauan belajar
16. Berkoperasi
5. Komitmen
17. Fleksibel
6. Motivasi
7. Bersemangat
18. Kerja dalam tim
19. Mandiri
8. Dapat diandalkan
20. Mendengarkan
9. Komunikasi lisan
21. Tangguh
10. Kreatif
22. Berargumentasi logis
11. Kemampuan analitis
23. Manajemen waktu
12. Dapat mengatasi stres

Secara garis besar, kemampuan intrapersonal mencakup beberapa aspek, yaitu: 1) Kesadaran diri (self awareness), yang didalamnya meliputi: kepercayaan diri, kemampuan untuk melakukan penilaian dirinya, pembawaan, serta kemampuan mengendalikan emosional, 2) Kemampuan diri (self skill), yang didalamnya meliputi: upaya peningkatan diri, kontrol diri, dapat dipercaya, dapat mengelola waktu dan kekuatan, proaktif, dan konsisten. Sedangkan kemampuan interpersonal juga mencakup beberapa aspek yaitu: 1) Aspek kesadaran sosial (social awareness), yang meliputi kemampuan kesadaran politik, pengembangan aspek-aspek yang lain, berorientasi untuk melayani, dan empati. 2) Aspek kemampuan sosial (social skill), yang meliputi kemampuan memimpin, mempunyai pengaruh, dapat berkomunikasi, mampu mengelola konflik, kooperatif dengan siapapun, dapat bekerja sama dengan tim, dan bersinergi.

\section{Pengembangan Soft Skill dalam Pembelajaran}

Atribut soft skill sebenarnya dimiliki oleh setiap orang, tetapi dalam jumlah dan kadar yang berbedabeda. Atribut tersebut dapat berubah jika yang bersangkutan mau mengubahnya. Atribut ini juga dapat 
dikembangkan menjadi karakter seseorang. Bagaimana mengubah atau mengembangkannya? Tidak lain tidak bukan, harus diasah dan dipraktekkan oleh setiap individu yang belajar atau ingin mengembangkannya. Salah satu ajang yang cukup baik untuk mengembangkan soft skill adalah melalui pembelajaran dengan segala aktivitasnya dan lembaga keMahasiswaan.

Soft skill merupakan kemampuan khusus, diantaranya meliputi social interaction, ketrampilan teknis dan managerial. Kemampuan ini adalah salah satu hal yang harus dimiliki tiap mahasiswa dalam memasuki dunia kerja. Gambaran mengenai persentase kemampuan seorang mahasiswa yang diperoleh dari kampus mereka. Berdasarkan data yang diadopsi dari Havard School of Bisnis, kemampuan dan keterampilan yang diberikan di bangku pembelajaran, 90 persen adalah kemampuan teknis dan sisanya soft skill. Padahal, yang nantinya diperlukan untuk menghadapi dunia kerja yaitu hanya sekitar 15 persen kemampuan hard skill. Dari data tersebut, lanjutnya, dapat menarik benang merah bahwa dalam memasuki dunia kerja soft skill-lah yang mempunyai peran yang lebih dominan.

\section{Mengembangkan Soft Skill Mahasiswa}

Untuk mendiseminasikan soft skill pada mahasiswa, faktor yang sangat berpengaruh adalah dimulai dari dosen. Maka, Ichard skillan yang juga turut merumuskan pengembangan soft skill, mendukung pelaksanaan pelatihan bagi para dosen supaya mengerti lebih jauh tentang soft skill. Menurutnya, dosen harus bisa jadi living example. Dari mulai datang tepat waktu, mengoreksi tugas, dan sebagainya. Bukan apa-apa, kemampuan presentasi dan menulis Mahasiswa masih banyak yang belum bagus. Dosen juga harus bisa melatih Mahasiswa supaya asertif, supaya berani membicarakan ide. Fenomena Mahasiswa menyontek juga jangan dianggap biasa, ini masuk faktor kejujuran dan etika dalam soft skill. Lihat di Indonesia, korupsi begitu menjamur, karena orang sudah terbiasa tidak jujur sejak masa sekolah.

Soft skill yang diberikan kepada mahasiswa dapat diintegrasikan dengan materi pembelajaran. Menurut Saillah (2007), materi soft skill yang perlu dikembangkan kepada mahasiswa, tidak lain adalah penanaman sikap jujur, kemampuan berkomunikasi, dan komitmen. Untuk mengembangkan soft skill dengan pembelajaran, perlu dilakukan perencanaan yang melibatkan para dosen, Mahasiswa, alumni, dan dunia kerja, untuk mengidentifikasi pengembangan soft skill yang relevan. Tentu saja pengidentifikasian tersebut bukan sesuatu yang "hitam-putih", tetapi lebih merupakan kesepakatan. Dengan asumsi semua dosen memahami betul "isi" pembelajaran yang dibina dan "memahami" konsep soft skill beserta komponen-komponennya, maka pengisian akan berlangung objektif dan cermat. Dengan cara itu setiap dosen mengetahui komponen soft skill apa yang harus dikembangkan ketika mengajar.

Hard skill dapat dinilai dari technical test atau practical test. Bagaimana untuk menilai soft skill Mahasiswa? Evaluasi dengan kertas dan pensil dengan jawaban tunggal (konvergen) tidak cukup. Perlu dilengkapi dengan model soal yang divergen dengan jawaban beragam. Ketika Mahasiswa mengidentifikasi informasi, sangat mungkin hasilnya beragam dan semuanya benar. Demikian pula ketika Mahasiswa menyampaikan pendapat. Komponen kesadaran diri juga lebih dekat dengan ranah afektif, sehingga evaluasinya tidak dapat hanya dengan tes. Diperlukan format observasi guna mengetahui apakah Mahasiswa memang sudah menghayati yang direpresentasikan dalam tindakan keseharian. Tes kinerja dan lembar observasi juga diperlukan untuk mengetahui kinerja Mahasiswa dalam mengerjakan tugas/tes maupun perilaku keseharian. Substansi ujian sebaiknya dikaitkan dengan masalah nyata, sehingga dapat menjadi bentuk authentic evaluation paling tidak berupa shadow authentic evaluation yang bersifat pemecahan masalah (problem based).

\section{METODE PENELITIAN}

Penelitian ini termasuk dalam kelompok penelitian survei dengan populasi seluruh mahasiswa program studi Pendidikan Ekonomi FKIP Universitas Jambi angkatan tahun 2015, 2016 dan 2017. Jumlah responden yang direncananakan setiap angkatan sebanyak 60 orang dengan demikian jumlah keseluruhan responden sebanyak180 orang. Adapun metodologi yang akan digunakan pada penelitian Penekanannya pada pengukuran kepemilikan atribut soft skills yang dimiliki mahasiswa Prodi Pendidikan Ekonomi FKIP UNJA dan derajad kepemilikan setiap atribut tersebut. Instrumen yang digunakan pada penelitian ini merupakan instrumen hasil penelitian pengembangan yang telah dikerjakan tahun 2017. Jumlah pertanyaan 
sebanyak 69 butir yang terkelompokkan dalam 23 kategori; setiap kategori terdiri atas 3 butir pernyataan. Data dikumpulkan menggunakan angket yang diberikan kepada mahasiswa secara langsung dan dikumpulkan pada hari yang sama. Hal ini ditempuh karena jika dikumpulkan dengan waktu bebas, berdasarkan pengalaman sebelumnya akan banyak yang tidak mengumpulkan kembali dengan berbagai alasan. Data yang telah terkumpul kemudian akan dianalisis secara deskriptif.

\section{HASIL DAN PEMBAHASAN}

Hasil dari penelitian ini berupa instrumen penilaian model pembelajaran soft skils yang telah melalui serangkaian validasi. Data yang dikumpulkan berupa penilaian dalam bentuk angket dari ahli instrumen terhadap instrumen instrumen soft skills yang dikembangkan melalui mahasiswa dengan menyebarkan angket kepada mahasiswa angkatan 2015, 2016 dan 2017 mahasiswa di Prodi Pendidikan Ekonomi Universitas Jambi.

Atribut soft skills apa saja yang sudah dimiliki mahasiswa secara keseluruhan Program Studi Pendidikan Ekonomi FKIP Universitas Jambi

Hasil dari atribut soft skill pada penelitian ini dapat disajikan dalam tabel tabel berikut ini:

Tabel 1.

Tabulasi Rata-rata Kemampuan Soft Skills Mahasiswa Prodi Pendidikan Ekonomi

\begin{tabular}{lll}
\hline \multirow{2}{*}{ Kemampuan Soft Skills Mhs } & Total & \\
& Frek. Absolut & Frek. Relatif \\
\hline Kurang Baik & 2 & $0,87 \%$ \\
Baik & 81 & $35,22 \%$ \\
Sangat Baik & 147 & $63,91 \%$ \\
Jumlah & 230 & $100,00 \%$ \\
\hline
\end{tabular}

Tabel 2.

Tabulasi Rata-rata Kemampuan Soft Skills Mahasiswa Prodi Pendidikan Ekonomi

\begin{tabular}{llllc}
\hline \multirow{2}{*}{ Kemampuan Soft Skills Mhs } & \multicolumn{2}{c}{ Mahasiswa Reguler } & \multicolumn{2}{c}{ Mahasiswa Mandiri } \\
& Frek. Absolut & Frek. Relatif & Frek. Absolut & Frek. Relatif \\
\hline Kurang Baik & - & - & 2 & $2,56 \%$ \\
Baik & 54 & $35,53 \%$ & 27 & $34,62 \%$ \\
Sangat Baik & 98 & $64,47 \%$ & 49 & $62,82 \%$ \\
Jumlah & 152 & $100,00 \%$ & 78 & $100,00 \%$ \\
\hline
\end{tabular}

Berdasarkan Tabel 1, Tabel 2 dan Gambar 1 dapat dipaparkan bahwa Kemampuan Soft Skills Mahasiswa Prodi Pendidikan Ekonomi memiliki sangat baik dengan Frekuensi Relatif 63,91\%. Bila dibedakan antara Mahasiswa Reguler Frek. Absolut 98 dan Frekuensi Relatif 64,47\% semtara Mahasiswa Mandiri Frek. Absolut 49 dan Frek. Relatif 62,82\% . Namun demikian sebagian kecil (1 65\%) peredaan antara Mahasiswa Reguler dan Mahasiswa Mandiri. Bila disajikan dalam bentuk Gambar 4.1 Bar Chart sebagai berikut:

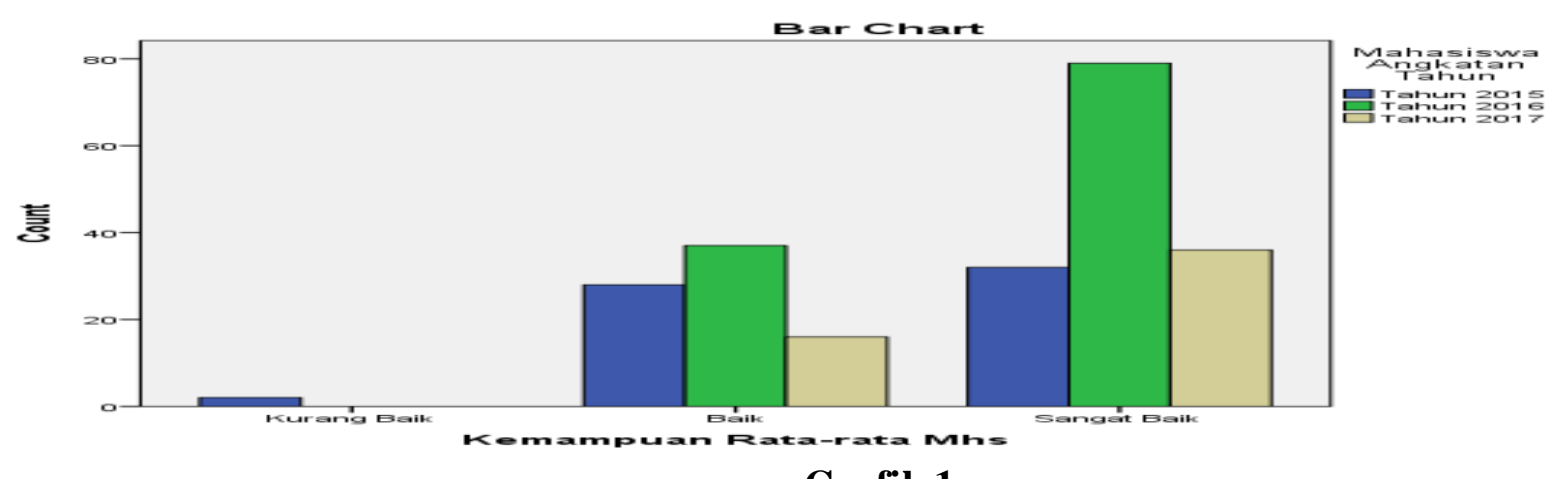

Grafik 1

Bar Chart Rata-rata Soft Skills Mahasiswa Angkatan Tahun 2015, 2016 dan 2017 
Dapat dilihat dari Grafik 1 Bar Chart Rata-rata Soft Skills Mahasiswa Angkatan Tahun 2015, 2016 dan 2017 bahwa hasil sangat baik menunjukkan 80\% dengan hasil tersebut menunjukkan bahwa kemampuan rata-rata sangat tinggi.

Kemampuan soft skills mahasiswa prodi Pendidikan Ekonomi angkatan tahun 2015 s.d 2017 dilihat dari 23 butir penilaian. Ke dua puluh tiga butir tersebut sbb:

Tabel 3.

Kemampuan soft skills mahasiswa prodi Pendidikan Ekonomi angkatan tahun 2015 s.d 2017

\begin{tabular}{llllllllll}
\hline \multirow{2}{*}{ No } & \multirow{2}{*}{ Keterangan Butir } & \multicolumn{2}{c}{ Sangat Kurang Baik } & \multicolumn{2}{c}{ Kurang Baik } & \multicolumn{2}{c}{ Baik } & \multicolumn{3}{c}{ Sangat Baik } \\
& Absl & Rel \% & Absl & Rel $\%$ & Absl & Rel \% & Absl & Rel $\%$ \\
\hline 1 & Inisiatif & 1 & 0,43 & 45 & 19,57 & 103 & 44,78 & 81 & 35,22 \\
2 & Integritas & 2 & 0,87 & 47 & 20,43 & 115 & 50,00 & 66 & 28,70 \\
3 & Berpikir Kritis & 1 & 0,43 & 49 & 21,30 & 101 & 43,91 & 79 & 34,35 \\
4 & Kemauan Belajar & 4 & 1,74 & 21 & 9,13 & 85 & 36,96 & 120 & 52,17 \\
5 & Komitmen & 5 & 2,17 & 18 & 7,83 & 101 & 43,91 & 106 & 46,09 \\
6 & Sikap Bersemangat & 3 & 1,30 & 34 & 14,78 & 89 & 38,70 & 104 & 45,22 \\
7 & Sikap Motivasi & 3 & 1,30 & 31 & 13,48 & 72 & 31,30 & 124 & 53,91 \\
8 & Keterandalan & 1 & 0,43 & 16 & 6,96 & 79 & 34,35 & 134 & 58,26 \\
9 & Komunikasi Lisan & 1 & 0,43 & 18 & 7,83 & 140 & 60,87 & 71 & 30,87 \\
10 & Kreatifitas & 3 & 1,30 & 48 & 20,87 & 99 & 43,04 & 80 & 34,78 \\
11 & Kemampuan Analisis & 2 & 0,87 & 29 & 12,61 & 138 & 60,00 & 61 & 26,52 \\
12 & Kemampuan Mengatasi Stress & 1 & 0,43 & 15 & 6,52 & 79 & 34,35 & 135 & 58,70 \\
13 & Manajemen Diri & - & & 3 & 1,30 & 26 & 11,30 & 201 & 87,39 \\
14 & Kemampuan & & & & 3,04 & 42 & 18,26 & 180 & 78,26 \\
& Persoalan & 1 & 0,43 & 7 & 30,26 & \\
15 & Kemampuan Meringkas & - & & 43 & 18,70 & 80 & 34,78 & 107 & 46,52 \\
16 & Kerjasama / Kooperasi & 1 & 0,43 & 10 & 4,35 & 50 & 21,74 & 169 & 73,48 \\
17 & Kefleksibelan / Flexibiltas & 2 & 0,87 & 17 & 7,39 & 82 & 35,65 & 129 & 56,09 \\
18 & Kerjasama Dalam Tim & - & & 18 & 7,83 & 81 & 35,22 & 131 & 56,96 \\
19 & Kemandirian & 2 & 0,87 & 21 & 9,13 & 67 & 29,13 & 140 & 60,87 \\
20 & Sikap Mendengarkan Orang Lain & 2 & 0,87 & 27 & 11,74 & 69 & 30,00 & 132 & 57,39 \\
21 & Ketangguhan & 2 & 0,87 & 45 & 19,57 & 84 & 36,52 & 99 & 43,04 \\
22 & Kemampuan Berargumentasi & 5 & 2,17 & 86 & 37,39 & 96 & 41,74 & 43 & 18,70 \\
23 & Manajemen Waktu & 3 & 1,30 & 48 & 20,87 & 94 & 40,87 & 85 & 36,96 \\
& Rata-rata & 1,96 & 0,85 & 30,26 & 37,28 & 85,74 & 37,28 & 112,04 & 48,71 \\
\hline
\end{tabular}

Dari tabel diatas terlihat bahwa Kemampuan soft skills mahasiswa prodi Pendidikan Ekonomi angkatan tahun 2015 s.d 2017 dilihat dari 23 butir penilaian. Ke dua puluh tiga butir tersebut sangat baik dapat dilihat dari rata-rata setiap butir 23 penilaian soft skill.

Kemampuan soft skills mahasiswa prodi Pendidikan Ekonomi Reguler angkatan tahun 2015 s.d 2017 dilihat dari 23 butir penilaian. Ke dua puluh tiga butir tersebut sbb:

Tabel 4.

Kemampuan soft skills mahasiswa prodi Pendidikan Ekonomi Reguler angkatan tahun 2015 s.d 2017

\begin{tabular}{|c|c|c|c|c|c|c|c|c|c|}
\hline \multirow{2}{*}{ No } & \multirow{2}{*}{ Keterangan Butir } & \multicolumn{2}{|c|}{ Sangat Kurang Baik } & \multicolumn{2}{|c|}{ Kurang Baik } & \multicolumn{2}{|l|}{ Baik } & \multicolumn{2}{|c|}{ Sangat Baik } \\
\hline & & Absl & $\operatorname{Rel} \%$ & Absl & $\operatorname{Rel} \%$ & Absl & $\operatorname{Rel} \%$ & Absl & $\operatorname{Rel} \%$ \\
\hline 1 & Inisiatif & 0 & 0,00 & 36 & 23,68 & 71 & 46,71 & 45 & 29,61 \\
\hline 2 & Integritas & 0 & 0,00 & 39 & 25,66 & 74 & 48,68 & 39 & 25,66 \\
\hline 3 & Berpikir Kritis & 0 & 0,00 & 35 & 23,03 & 70 & 46,05 & 47 & 30,92 \\
\hline 4 & Kemauan Belajar & 2 & 1,32 & 11 & 7,24 & 57 & 37,50 & 82 & 53,95 \\
\hline 5 & Komitmen & 3 & 1,97 & 14 & 9,21 & 67 & 44,08 & 68 & 44,74 \\
\hline 6 & Sikap Bersemangat & 1 & 0,66 & 27 & 17,76 & 62 & 40,79 & 62 & 40,79 \\
\hline 7 & Sikap Motivasi & 1 & 0,66 & 22 & 14,47 & 49 & 32,24 & 80 & 52,63 \\
\hline 8 & Keterandalan & 0 & 0,00 & 10 & 6,58 & 55 & 36,18 & 87 & 57,24 \\
\hline 9 & Komunikasi Lisan & 0 & 0,00 & 9 & 5,92 & 99 & 65,13 & 44 & 28,95 \\
\hline 10 & Kreatifitas & 2 & 1,32 & 37 & 24,34 & 59 & 38,82 & 54 & 35,53 \\
\hline 11 & Kemampuan Analisis & 0 & 0,00 & 23 & 15,13 & 95 & 62,50 & 34 & 22,37 \\
\hline 12 & Kemampuan Mengatasi Stress & 1 & 0,66 & 11 & 7,24 & 54 & 35,53 & 86 & 56,58 \\
\hline
\end{tabular}




\begin{tabular}{|c|c|c|c|c|c|c|c|c|c|}
\hline \multirow{2}{*}{$\begin{array}{l}13 \\
14\end{array}$} & Manajemen Diri & 2 & 1,32 & 7 & 4,61 & 143 & 94,08 & 152 & 100,00 \\
\hline & Persoalan & 0 & 0,00 & 0 & 0,00 & 20 & 13,16 & 132 & 86,84 \\
\hline 15 & Kemampuan Meringkas & 0 & 0,00 & 30 & 19,74 & 60 & 39,47 & 62 & 40,79 \\
\hline 16 & Kerjasama / Kooperasi & 1 & 0,66 & 6 & 3,95 & 28 & 18,42 & 117 & 76,97 \\
\hline 17 & Kefleksibelan / Flexibiltas & 1 & 0,66 & 12 & 7,89 & 49 & 32,24 & 90 & 59,21 \\
\hline 18 & Kerjasama Dalam Tim & 0 & 0,00 & 12 & 7,89 & 55 & 36,18 & 85 & 55,92 \\
\hline 19 & Kemandirian & 0 & 0,00 & 11 & 7,24 & 45 & 29,61 & 96 & 63,16 \\
\hline 20 & $\begin{array}{l}\text { Sikap Mendengarkan Orang } \\
\text { Lain }\end{array}$ & 0 & 0,00 & 20 & 13,16 & 42 & 27,63 & 90 & 59,21 \\
\hline 21 & Ketangguhan & 0 & 0,00 & 30 & 19,74 & 60 & 39,47 & 62 & 40,79 \\
\hline 22 & Kemampuan Berargumentasi & 2 & 1,32 & 53 & 34,87 & 76 & 50,00 & 21 & 13,82 \\
\hline 23 & Manajemen Waktu & 0 & 0,00 & 31 & 20,39 & 69 & 45,39 & 52 & 34,21 \\
\hline \multicolumn{2}{|c|}{ Rata-rata } & 0,70 & 0,44 & 21,13 & 13,32 & 63,43 & 39,99 & 73,35 & 46,24 \\
\hline
\end{tabular}

Tabel 5.

Kemampuan soft skills mahasiswa prodi Pendidikan Ekonomi Mandiri angkatan tahun 2015 s.d 2017 dilihat dari 23 butir penilaian.

\begin{tabular}{|c|c|c|c|c|c|c|c|c|c|}
\hline \multirow{2}{*}{ No } & \multirow{2}{*}{ Keterangan Butir } & \multirow{2}{*}{$\begin{array}{l}\text { Sangat } \\
\text { Baik } \\
\text { Absl }\end{array}$} & \multirow{2}{*}{$\begin{array}{l}\text { Kurang } \\
\text { Rel \% }\end{array}$} & \multicolumn{2}{|c|}{ Kurang Baik } & \multicolumn{2}{|l|}{ Baik } & \multicolumn{2}{|c|}{ Sangat Baik } \\
\hline & & & & Absl & $\operatorname{Rel} \%$ & Absl & $\operatorname{Rel} \%$ & Absl & $\operatorname{Rel} \%$ \\
\hline 1 & Inisiatif & 1 & 1,28 & 9 & 11,54 & 32 & 41,03 & 36 & 46,15 \\
\hline 2 & Integritas & 2 & 2,56 & 2 & 2,56 & 41 & 52,56 & 27 & 34,62 \\
\hline 3 & Berpikir Kritis & 1 & 1,28 & 14 & 17,95 & 31 & 39,74 & 32 & 41,03 \\
\hline 4 & Kemauan Belajar & 2 & 2,56 & 10 & 12,82 & 28 & 35,90 & 38 & 48,72 \\
\hline 5 & Komitmen & 2 & 2,56 & 4 & 5,13 & 34 & 43,59 & 38 & 48,72 \\
\hline 6 & Sikap Bersemangat & 2 & 2,56 & 7 & 8,97 & 27 & 34,62 & 42 & 53,85 \\
\hline 7 & Sikap Motivasi & 2 & 2,56 & 9 & 11,54 & 23 & 29,49 & 44 & 56,41 \\
\hline 8 & Keterandalan & 1 & 1,28 & 6 & 7,69 & 24 & 30,77 & 47 & 60,26 \\
\hline 9 & Komunikasi Lisan & 1 & 1,28 & 9 & 11,54 & 41 & 52,56 & 27 & 34,62 \\
\hline 10 & Kreatifitas & 1 & 1,28 & 11 & 14,10 & 40 & 51,28 & 26 & 33,33 \\
\hline 11 & Kemampuan Analisis & 2 & 2,56 & 6 & 7,69 & 43 & 55,13 & 27 & 34,62 \\
\hline 12 & Kemampuan Mengatasi Stress & 0 & 0,00 & 4 & 5,13 & 25 & 32,05 & 49 & 62,82 \\
\hline \multirow{2}{*}{$\begin{array}{l}13 \\
14\end{array}$} & Manajemen Diri & 0 & 0,00 & 1 & 1,28 & 19 & 24,36 & 58 & 74,36 \\
\hline & $\begin{array}{l}\text { Kemampuan } \\
\text { Persoalan }\end{array}$ & 0 & 0,00 & 7 & 8,97 & 22 & 28,21 & 48 & 61,54 \\
\hline 15 & Kemampuan Meringkas & 0 & 0,00 & 13 & 16,67 & 20 & 25,64 & 45 & 57,69 \\
\hline 16 & Kerjasama / Kooperasi & 0 & 0,00 & 4 & 5,13 & 22 & 28,21 & 52 & 66,67 \\
\hline 17 & Kefleksibelan / Flexibiltas & 1 & 1,28 & 5 & 6,41 & 33 & 42,31 & 39 & 50,00 \\
\hline 18 & Kerjasama Dalam Tim & 0 & 0,00 & 6 & 7,69 & 26 & 33,33 & 46 & 58,97 \\
\hline 19 & Kemandirian & 2 & 2,56 & 10 & 12,82 & 22 & 28,21 & 44 & 56,41 \\
\hline 20 & Sikap Mendengarkan Orang Lain & 2 & 2,56 & 7 & 8,97 & 27 & 34,62 & 42 & 53,85 \\
\hline 21 & Ketangguhan & 2 & 2,56 & 15 & 19,23 & 24 & 30,77 & 37 & 47,44 \\
\hline 22 & Kemampuan Berargumentasi & 3 & 3,85 & 33 & 42,31 & 20 & 25,64 & 22 & 28,21 \\
\hline 23 & Manajemen Waktu & 3 & 3,85 & 17 & 21,79 & 25 & 32,05 & 33 & 42,31 \\
\hline \multicolumn{2}{|c|}{ Rata-rata } & 1,30 & 1,68 & 9,09 & 11,70 & 28,22 & 36,32 & 39,09 & 50,31 \\
\hline
\end{tabular}

Jika kedua kelompok yaitu Mahasiswa Reguler dan Mahasiswa Mandiri diperbandingkan, apakah ada beda yang signifikan diantara kedianya hasilnya sebagai berikut:

Tabel 6.

Uji perbedaan antara Kelompok Mahasiswa Reguler dan Mandiri

\begin{tabular}{|c|c|c|c|c|c|c|c|c|c|}
\hline \multicolumn{10}{|c|}{ Paired Samples Test } \\
\hline & & \multicolumn{5}{|c|}{ Paired Differences } & \multirow{3}{*}{$\mathrm{t}$} & \multirow{3}{*}{ df } & \multirow{3}{*}{ Sig. (2-tailed) } \\
\hline & & \multirow[t]{2}{*}{ Mean } & \multirow{2}{*}{$\begin{array}{l}\text { Std. } \\
\text { Deviation }\end{array}$} & \multirow{2}{*}{$\begin{array}{ll}\text { Std. } & \text { Error } \\
\text { Mean } & \end{array}$} & \multicolumn{2}{|c|}{$\begin{array}{l}95 \% \text { Confidence Interval of the } \\
\text { Difference }\end{array}$} & & & \\
\hline & & & & & Lower & Upper & & & \\
\hline $\begin{array}{l}\text { Pair } \\
1\end{array}$ & $\begin{array}{l}\text { Reguler } \\
\text { - } \\
\text { Mandiri }\end{array}$ & -.00500 & 3.37618 & 1.68809 & -5.37725 & 5.36725 & -.003 & 3 & .998 \\
\hline
\end{tabular}


Artinya kedua kelompok tidak berbeda secara signifikan hal ini ditunukkan dengan koefisen $\mathrm{t}-0,003$ dengan signifikansi 0,998. Dari hasil tersebut dapat dilihat bahwa uji perbedaan antara Kelompok Mahasiswa Reguler dan Mandiri Sig. (2-tailed) 0.998 dengan Std. Deviation 3.37618 bahawa kemampuan soft skill antara Kelompok Mahasiswa Reguler dan Mandiri bahawa Mahasiswa Reguler lebih tinggi.

\section{Kemampuan Soft Skills Mahasiswa Secara per angkatan 2015, 2016 dan 2017 Program Studi Pendidikan Ekonomi FKIP Universitas Jambi}

Adapun hasil dari kemampuan soft skill pada penelitian ini dapat disajikan dalam tabel tabel berikut ini:

Tabel 7.

Tabulasi Rata-rata Kemampuan Soft Skills Mahasiswa Prodi Pendidikan Ekonomi Angkatan Tahun 2015, 2016 dan 2017

\begin{tabular}{|c|c|c|c|c|c|c|}
\hline \multirow{2}{*}{ Kemampuan Soft Skills Mhs } & $\begin{array}{l}\text { Mahasiswa } \\
2015\end{array}$ & Angkatan Tahun & $\begin{array}{l}\text { Mahasiswa } \\
2016\end{array}$ & Angkatan Tahun & $\begin{array}{l}\text { Mahasiswa } \\
2017\end{array}$ & Angkatan Tahun \\
\hline & $\begin{array}{l}\text { Frek. } \\
\text { Absolut }\end{array}$ & Frek. Relatif & $\begin{array}{l}\text { Frek. } \\
\text { Absolut }\end{array}$ & Frek. Relatif & $\begin{array}{l}\text { Frek. } \\
\text { Absolut }\end{array}$ & Frek. Relatif \\
\hline Kurang Baik & 2 & $2,22 \%$ & 0 & - & 0 & - \\
\hline Baik & 28 & $45,16 \%$ & 37 & $31,90 \%$ & 16 & $30,77 \%$ \\
\hline Sangat Baik & 32 & $51,61 \%$ & 79 & $68,10 \%$ & 36 & $69,23 \%$ \\
\hline Jumlah & 62 & $100,00 \%$ & 116 & $100,00 \%$ & 52 & $100,00 \%$ \\
\hline
\end{tabular}

Tabel 8.

Atribut Soft Skill Mahasiswa Reguler dan Mandiri Angkatan Tahun 2015, 2016 dan 2017

\begin{tabular}{llllll}
\hline & & & \multicolumn{2}{l}{ Reguler dan Non Reguler } \\
Mahasiswa Angkatan Tahun & & Reguler & Non Reguler & Total \\
\hline Tahun 2015 & Kemampuan Rata-rata Mhs & Kurang Baik & 0 & 2 & 2 \\
& & 12 & 16 & 28 \\
& & Baik & 20 & 12 & 32 \\
\multirow{5}{*}{ Tahun 2016 } & Sangat Baik & 32 & 30 & 62 \\
& Total & & 27 & 10 & 37 \\
\multirow{5}{*}{ Tahun 2017} & Kemampuan Rata-rata Mhs & Baik & 51 & 28 & 79 \\
& & Sangat Baik & 78 & 38 & 116 \\
& Total & & 15 & 1 & 16 \\
Total & Kemampuan Rata-rata Mhs & Baik & 27 & 9 & 36 \\
& Total & Sangat Baik & 42 & 10 & 52 \\
& Kemampuan Rata-rata Mhs & Kurang Baik & 0 & 2 & 2 \\
& & Baik & 54 & 27 & 81 \\
& & Total & 98 & 49 & 147 \\
& & & 152 & 78 & 230 \\
\hline
\end{tabular}

Berdasarkan tabel 8 bahwa Kemampuan Soft Skills Mahasiswa angkatan tahun 2017 sangat baik dengan frekuensi absolut 36 dan frekuensi relative 69,23\% dengan perbandingan Mahasiswa Angkatan Tahun 2015 dan 2016, sesuai dengan table tersebut dapat dilihat bahwa Kemampuan Soft Skills Mahasiswa perangkatan mengalami kenaikan dari tahun 2015 sampai dengan 2017.

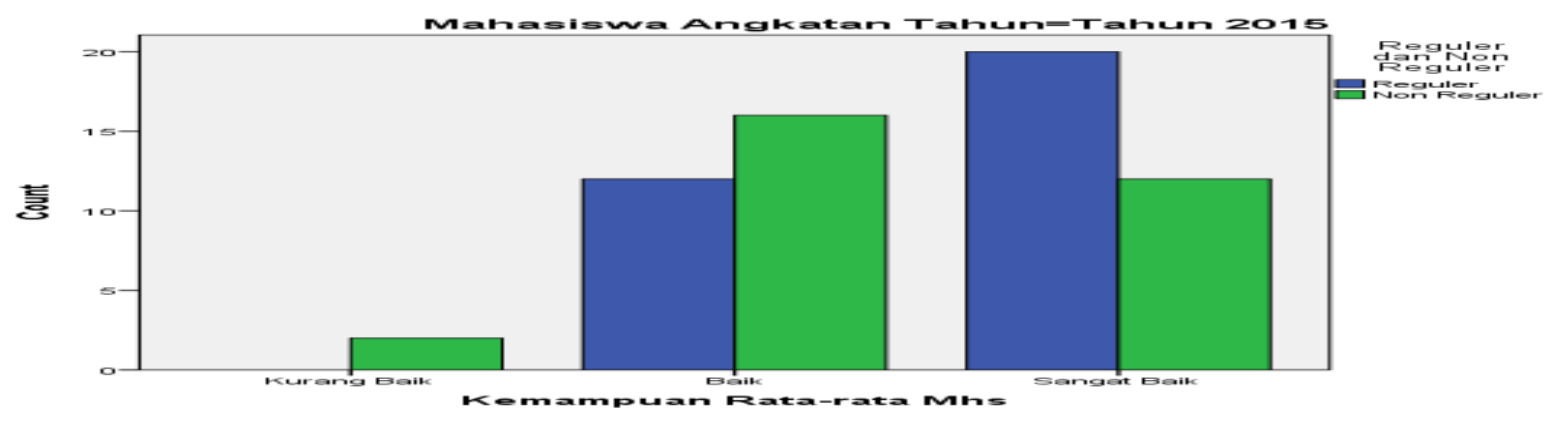

Grafik 2

Bar Chart Rata-rata Soft Skills Mahasiswa Reguler dan Mandiri Angkatan Tahun 2015 


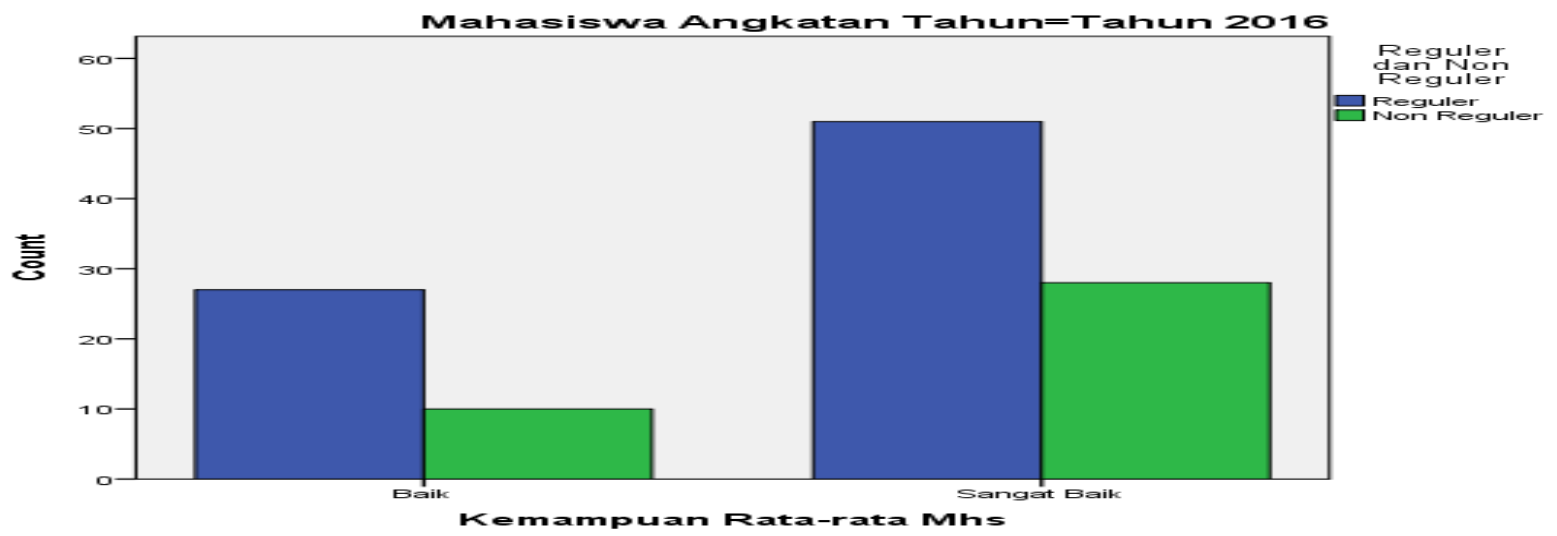

Grafik 3

Bar Chart Rata-rata Soft Skills Mahasiswa Reguler dan Mandiri Angkatan Tahun 2016

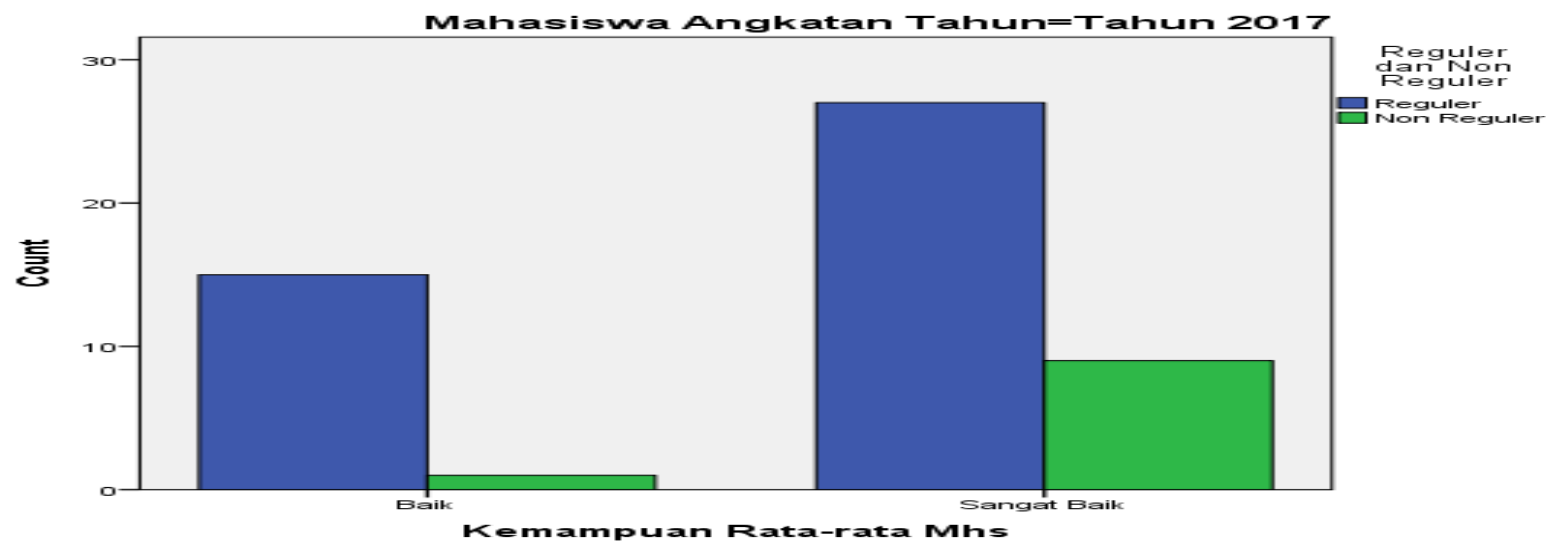

Grafik 4

Bar Chart Rata-rata Soft Skills Mahasiswa Reguler dan Mandiri Angkatan Tahun 2017

Dilihat dari hasil Grafik 4 Bar Chart Rata-rata Soft Skills Mahasiswa Reguler dan Mandiri Angkatan Tahun 2015, 2016 dan 2017 dapat dilihat hasilnya sangat memuaskan.

Kemampuan Berdasarkan Gender Soft Skills mahasiswa Program Studi Pendidikan Ekonomi FKIP Universitas Jambi

Kemampuan Soft Skill Mahasiswa Berdasarkan Jenis Kelamin hasilnya dapat dilihat pada tabel sebagai berikut:

Tabel 9.

Kemampuan Umum Soft Skills Mahasiswa Berdasarkan Jenis Kelamin

\begin{tabular}{|c|c|c|c|c|c|c|}
\hline & & & $\begin{array}{l}\text { Kemamp } \\
\text { Kurang } \\
\text { Baik }\end{array}$ & Rata-rata & Sangat Baik & Total \\
\hline Jenis & Laki-laki & Count & 0 & 20 & 25 & 45 \\
\hline \multirow[t]{7}{*}{ Kelamin } & & $\%$ within Jenis Kelamin & $0.0 \%$ & $44.4 \%$ & $55.6 \%$ & $100.0 \%$ \\
\hline & & $\%$ within Kemampuan Rata-rata Mhs & $0.0 \%$ & $24.7 \%$ & $17.0 \%$ & $19.6 \%$ \\
\hline & & $\%$ of Total & $0.0 \%$ & $8.7 \%$ & $10.9 \%$ & $19.6 \%$ \\
\hline & Perempuan & Count & 2 & 61 & 122 & 185 \\
\hline & & $\%$ within Jenis Kelamin & $1.1 \%$ & $33.0 \%$ & $65.9 \%$ & $100.0 \%$ \\
\hline & & $\%$ within Kemampuan Rata-rata Mhs & $100.0 \%$ & $75.3 \%$ & $83.0 \%$ & $80.4 \%$ \\
\hline & & $\%$ of Total & $0.9 \%$ & $26.5 \%$ & $53.0 \%$ & $80.4 \%$ \\
\hline \multirow[t]{4}{*}{ Total } & & Count & 2 & 81 & 147 & 230 \\
\hline & & $\%$ within Jenis Kelamin & $0.9 \%$ & $35.2 \%$ & $63.9 \%$ & $100.0 \%$ \\
\hline & & $\%$ within Kemampuan Rata-rata Mhs & $100.0 \%$ & $100.0 \%$ & $100.0 \%$ & $100.0 \%$ \\
\hline & & $\%$ of Total & $0.9 \%$ & $35.2 \%$ & $63.9 \%$ & $100.0 \%$ \\
\hline
\end{tabular}


Kemampuan Soft Skill Mahasiswa Berdasarkan Jenis Kelamin Tabel 4.8 Kemampuan Umum Soft Skills Mahasiswa Berdasarkan Jenis Kelamin bahwa perempuan libih tinggi dari pada laki-lakin dengan kemampuan rata-rata sangat baik dengan hasil count 25 untuk laki-laki dan perempuan count 122.

Tabel 10.

Kemampuan Rata-rata Mhs dan Jemis Kelamin

ANOVA

\begin{tabular}{|l|l|l|l|l|l|}
\hline & Sum of Squares & df & Mean Square & F & Sig. \\
\hline Between Groups & .314 & 1 & .314 & 1.249 & .265 \\
\hline Within Groups & 57.273 & 228 & .251 & & \\
\hline Total & 57.587 & 229 & & & \\
\hline
\end{tabular}

Hasil analisis menunjukkan bahwa nilai $F=1,249$ dengan tingkat penolakan 26,5 artinya jika Penelitian ini menetapkan tingkat penolakan sebesar 5\% maka hasil Penelitian ini menujukkan tidak ada ada perbedaan pemilikan kemampuan soft skills mahasiswa antara jenis kelamin laki-laki dan perempuan.

\section{Soft Skills mahasiswa Program Studi Pendidikan Ekonomi FKIP Universitas Jambi berdasarkan asal dari kampung dan kota Asal Mahasiswa * Kemampuan Rata-rata Mhs Crosstabulation}

Tabel 11.

Kemampuan Umum Soft Skills Mahasiswa Berdasarkan Asal Tempat Tinggal

\begin{tabular}{|c|c|c|c|c|c|c|}
\hline & & & \multicolumn{4}{|c|}{ Kemampuan Rata-rata Mhs } \\
\hline & & & Kurang Baik & Baik & Sangat Baik & Total \\
\hline \multirow[t]{8}{*}{ Asal Mahasiswa } & Kota & Count & 1 & 24 & 41 & 66 \\
\hline & & $\%$ within Asal Mahasiswa & $1.5 \%$ & $36.4 \%$ & $62.1 \%$ & $100.0 \%$ \\
\hline & & $\%$ within Kemampuan Rata-rata Mhs & $50.0 \%$ & $29.6 \%$ & $27.9 \%$ & $28.7 \%$ \\
\hline & & $\%$ of Total & $0.4 \%$ & $10.4 \%$ & $17.8 \%$ & $28.7 \%$ \\
\hline & Desa & Count & 1 & 57 & 106 & 164 \\
\hline & & $\%$ within Asal Mahasiswa & $0.6 \%$ & $34.8 \%$ & $64.6 \%$ & $100.0 \%$ \\
\hline & & $\%$ within Kemampuan Rata-rata Mhs & $50.0 \%$ & $70.4 \%$ & $72.1 \%$ & $71.3 \%$ \\
\hline & & $\%$ of Total & $0.4 \%$ & $24.8 \%$ & $46.1 \%$ & $71.3 \%$ \\
\hline \multirow[t]{4}{*}{ Total } & & Count & 2 & 81 & 147 & 230 \\
\hline & & $\%$ within Asal Mahasiswa & $0.9 \%$ & $35.2 \%$ & $63.9 \%$ & $100.0 \%$ \\
\hline & & $\%$ within Kemampuan Rata-rata Mhs & $100.0 \%$ & $100.0 \%$ & $100.0 \%$ & $100.0 \%$ \\
\hline & & $\%$ of Total & $0.9 \%$ & $35.2 \%$ & $63.9 \%$ & $100.0 \%$ \\
\hline
\end{tabular}

Tabel 12.

Kemampuan Rata-rata Mhs dan Asal Tempat Tinggal Mahasiswa

Anava

\begin{tabular}{|l|l|l|l|l|l|}
\hline & Sum of Squares & df & Mean Square & F & Sig. \\
\hline Between Groups & .055 & 1 & .055 & .218 & .641 \\
\hline Within Groups & 57.532 & 228 & .252 & & \\
\hline Total & 57.587 & 229 & & & \\
\hline
\end{tabular}

Hasil analisis diperoleh koefesien $\mathrm{F}$ hitung sebesar 0,218 dengan tingkat penolakan 64,10\% dengan demikian tidak ada bedanya kemampuan rata-rata soft skills mahasiswa mahasiswa yang berasal dari kota dan dari desa. Dengan itu dapat dilihat bahawa mahasiswa dari desa lebih tinggi soft skillsnya dari pada mahasiswa dari kota.

\section{SIMPULAN}

Berdasarkan hasil penelitian Analisis Kepemilikan Soft Skill mahasiswa Program Studi Pendidikan Ekonomi FKIP Universitas Jambi dapat disimpulkan bahwa 1) atribut soft skills yang sudah dimiliki mahasiswa secara keseluruhan sangat baik dengan Frekuensi Relatif 63,91\%,2) kemampuan soft skills mahasiswa secara per angkatan , 2015, 2016 dan 2017 sangat baik dengan frekuensi absolut 36 dan frekuensi relative 69,23\% dan Kemampuan Soft Skills Mahasiswa perangkatan mengalami kenaikan dari 
tahun 2015 sampai dengan 2017, 3) kemampuan berdasarkan gender Soft Skills mahasiswa yang berjenis kelamin perempuan lebih tinggi dari pada laki-lakin dengan kemampuan rata-rata sangat baik dengan hasil count 25 untuk laki-laki dan perempuan count 122, dan 4) Soft Skills mahasiswa berdasarkan asal dari kampung dan kota, hasil analisis diperoleh koefesien $\mathrm{F}$ hitung sebesar 0,218 dengan tingkat penolakan 64,10\% dengan demikian tidak ada bedanya kemampuan rata-rata soft skills mahasiswa mahasiswa yang berasal dari kota dan dari desa. Dengan itu dapat dilihat bahawa mahasiswa dari desa lebih tinggi soft skillsnya dari pada mahasiswa dari kota.

Adapun saran yang dapat diberikan dalam penelitian ini adalah 1) Analisis Kepemilikan Soft Skill mahasiswa Program Studi Pendidikan Ekonomi FKIP Universitas Jambi dapat dijadikan sebagai instrumen model pembelajaran soft skills untuk kelompok maupun individu, 2) Instrumen penilaian model pembelajaran soft skills mengenai hubungan interpersonal mahasiswa dapat menjadi acuan bagi dosen dalam menilai kemampuan soft skills mahasiswa secara objektif. 3) Sebelum menggunakan instrumen penilaian soft skills mengenai hubungan interpersonal mahasiswa, kita harus terlebih dahulu mempelajari dan memahami petunjuk penilaian instrument, tata cara penilaian dan inti dari penilaian pada setiap rubriknya. Sehingga pada saat pelaksanaan tidak memakan waktu yang lama dalam membaca kriteria penilaian pada rubrik dan focus pada arah soft skills yang akan di ajarkan.

\section{DAFTAR PUSTAKA}

Abbas, R., Abdul Kadir, F. A., \& Ghani Azmie, I. A. 2013. Integrating Soft Skills Assessment Through Soft Skills Workshop Program For Engineering Students At University Of Pahang: An Analysis. International Journal of Research In Social Science, 2(1), 33-46.

Anthony, S. ,2014. Integrating Soft Skills in the Curriculum without Sacrificing Content. Journal for Academic Excellence, 2(4), 1-57.

Azwar Saifuddin. 2014. Reliabilitas dan Validitas. Yogyakarta:Pustaka Pelajar

Cimatti, B. 2016. Definition, Development, Assesment of Soft Skill and Their Role for The Quality of Organizations and Enterprises. International Journal for Quality Research, 10(1), 97-130.

Djaali \& Pudji, M. 2012, Pengukuran dalam Bidang Pendidikan. Jakarta : Grasindo.

Haryati, Sri, 2012, Research and Development (R\&D) Sebagai Salah Satu Model Penelitian Dalam Bidang

Pendidikan, Vol 35 No.1 Tanggal 15 September $2012: 11-26$

Herlambang, Susatyo, 2012, Personality development, Yogyakarta : Gosyen Publishing.

Ibrahim, Amin, 2015, Teori dan Konsep Pelayanan Publik Serta Implementasinya, Bandung : Mandar Maju. Illah, Sailah, 2013, Pengembangan Soft Skill di Perguruan Tinggi: Eidi Revisi, Jakarta ; Direktorat Jendral Perguruan Tinggi.

Ilias, A., Abd Razak, M. Z., Yeop Yunus, N. K., \& Abd Razak, S. F. 2012. How Accounting Students Perceived Towards Teamwork Skills. Journal of Education and Vocational Research, 3(12), 387-398.

Lawrence A.Pervin, 2015, Psikologi Kepribadian, Jakarta : Kencana.

Muqowim, 2012, Pengembangan Soft Skill Guru, Yogyakarta : Pedagogia.

Majid, S., Liming, Z., Tong, S., \& Raihana, S. 2012. Importance of Soft Skills for Education and Career Success. International Journal for Cross-Disciplinary Subjects in Education (IJCDSE), 2(2), 10361042.

Myers, T., Blackman, A., Andersen, T., Hay, R., \& Lee, I. 2014. Cultivating ICT Student's International Soft Skills In Online Learning Environments Using Traditional Active Learning Techniques. Journal of Learning Design, 7(3), 38-53.

Naga, D. Santun. 2013. Teori Sekor Pada Pengukuran Mental. Jakarta: Nagarani Citrayasa

Nealy, C. 2015. Integrating Soft Skills Through Active Learning In The Management Classroom. Journal of College Teaching \& Learning, 2(4), 1-6.

Nugrohadi, Edwi dkk, 2013, Menjadi Pribadi Religius dan Humanis, Yogyakarta : Graha Ilmu.

Paolini, A. C. 2015. School Counselor's Role in Facilitating the Development of Students' Soft Skills: Intrapersonal and Interpersonal Attributes to Promote Career Readiness. Global Journal of HumanSocial Science, 15(10), 1-10.

Ramlall, S., \& Ramlall, D. 2014. The Value of Soft-Skills in the Accounting Profession: Perspectives of Current Accounting Students. Advances in Research, 2(11), 645-654. 
Richer, Rita C, Klein, 2012, Design and Developmen Research : An Introduction, Fifth Edition, New York : Longman.

Robles, M. 2012. Executive Perceptions of the Top 10 Soft Skills Needed in Today's Workplace. Business Communication Quarterly, 75(4), 453-465.

Sudaryono dkk, 2013, Pengembangan Instrumen Penelitian Pendidikan, Yogyakarta : Graha Ilmu.

Suryabrata, Sumadi. 2014. Metodologi Penelitian. Jakarta: Rajawali Pers.

Syaodih, Nana Sukmadinata,2012. Metode Penelitian Pendidikan, Bandung : PT Remaja Rosdakarya

Taylor, E. 2016. Investigating the Perception of Stakeholders on Soft Skills Development of Students: Evidence from South Africa. Interdisciplinary Journal of e-Skills and Lifelong Learning, 12(1), 1-18.

Wahyu Widhiarso, 2012. Evaluasi Soft Skills Dalam Konteks Pembelajaran. BENEFIT Jurnal Manajemen dan Bisnis Volume 17, Nomor 3, Desember 2012, hlm 79-90.

Wisnuwardhani dan Mashoedi, 2012, Hubungan Interpersonal, Jakarta : Salemba Humanika. 